\title{
Future Change in Tropical Cyclone Activity over the Western North Pacific in CORDEX-East Asia Multi-RCMs Forced by HadGEM2-AO
}

\author{
Hyeonjae Lee, ${ }^{a}$ Chun-Sil Jin, ${ }^{b}$ Dong-Hyun Cha, ${ }^{a}$ Minkyu Lee,,${ }^{a}$ Dong-Kyou Lee, ${ }^{c}$ \\ MYOUnG-SEOK SuH, ${ }^{\text {d }}$ SONG-YOU HONG, ${ }^{\text {e }}$ AND HYUn-SuK KANG ${ }^{\mathrm{f}}$ \\ ${ }^{a}$ Ulsan National Institute of Science and Technology, Ulsan, South Korea \\ ${ }^{\mathrm{b}}$ Korea Institute of Nuclear Safety, Daejeon, South Korea \\ ${ }^{\mathrm{c}}$ Seoul National University, Seoul, South Korea \\ ${ }^{\mathrm{d}}$ Kongju National University, Kongju, South Korea \\ ${ }^{\mathrm{e}}$ Korea Institute of Atmospheric Prediction Systems, Seoul, South Korea \\ ${ }^{\mathrm{f}}$ Korea Meteorological Administration, Seoul, South Korea
}

(Manuscript received 31 August 2018, in final form 12 May 2019)

\begin{abstract}
Future changes in tropical cyclone (TC) activity over the western North Pacific (WNP) are analyzed using four regional climate models (RCMs) within the Coordinated Regional Climate Downscaling Experiment (CORDEX) for East Asia. All RCMs are forced by the HadGEM2-AO under the historical and representative concentration pathway (RCP) 8.5 scenarios, and are performed at about $50-\mathrm{km}$ resolution over the CORDEX-East Asia domain. In the historical simulations (1980-2005), multi-RCM ensembles yield realistic climatology for TC tracks and genesis frequency during the TC season (June-November), although they show somewhat systematic biases in simulating TC activity. The future (2024-49) projections indicate an insignificant increase in the total number of TC genesis $(+5 \%)$, but a significant increase in track density over East Asia coastal regions ( $+17 \%)$. The enhanced TC activity over the East Asia coastal regions is mainly related to vertical wind shear weakened by reduced meridional temperature gradient and increased sea surface temperature (SST) at midlatitudes. The future accumulated cyclone energy (ACE) of total TCs increases significantly $(+19 \%)$ because individual TCs have a longer lifetime $(+6.6 \%)$ and stronger maximum wind speed $(+4.1 \%)$ compared to those in the historical run. In particular, the ACE of TCs passing through $25^{\circ} \mathrm{N}$ increases by $45.9 \%$ in the future climate, indicating that the destructiveness of TCs can be significantly enhanced in the midlatitudes despite the total number of TCs not changing greatly.
\end{abstract}

\section{Introduction}

Tropical cyclone (TC) is one of the high-impact natural hazards on Earth and humanity. The coastal regions of western North Pacific (WNP) with about 1.5 billion inhabitants are generally affected by more TCs compared with other ocean basins. Also, TCs have historically caused massive damage to human life and property in East Asia (Zhang et al. 2009). Therefore, accurate information on TC activities is necessary to reduce the casualty and property damage. In particular, the estimation of future changes in TC activities is required, since the characteristics of TCs tend to alter under changing climate.

Many previous studies have examined the change in TC activity induced by global warming using general

\footnotetext{
Corresponding author: Dong-Hyun Cha, dhcha@unist.ac.kr
}

circulation models (GCMs). Many international institutes have conducted experiments with phase 5 of the Coupled Model Intercomparison Project (CMIP5) (Camargo 2013). GCMs have demonstrated the production of TC-like vortices and large-scale variables related to TC activities (Bengtsson et al. 1982; Vitart et al. 1997). They have simulated realistic TC genesis locations or tracks but show low predictability in genesis frequency and intensity because of coarse resolution. To overcome the limitation of the resolution, some studies have examined applying high resolution to GCMs, but it resulted in a limitation in the decadal simulation because of a lack of computing resources (Murakami et al. 2012). Other methods to address the low-resolution problem of GCMs include the use of regional dynamical or statistical-dynamical downscaling techniques. The regional climate model (RCM), a technique of regional dynamical downscaling, shows more realistic TC 
genesis frequency or TC structure than the GCM (Emanuel et al. 2008; Bender et al. 2010). However, RCMs have suffered from the mismatch of physics between RCM and GCM, the lack of feedback of the simulated storm to the global climate system, and inherent uncertainties and systematic error induced by a single RCM (Emanuel 2013).

Nevertheless, the future change in TC activities over the WNP has been analyzed by RCM because of its specialized regional feature and high-resolution projection. Many previous studies have forecast a decreasing tendency in future total TC genesis frequency and an increasing trend in intense TC over the WNP (Bengtsson et al. 2007; Murakami et al. 2011a, 2012). Even though some studies have suggested a decrease in TC intensity (Hasegawa and Emori 2005) or an increase in TC genesis frequency (Stowasser et al. 2007), those studies have especially employed different domains and physics, which has resulted in inconsistent results. In this regard, the new international project Coordinated Regional Climate Downscaling Experiment (CORDEX), initiated by the World Climate Research Programme (WCRP), provides intercomparison and evaluation RCMs and produces a new generation of climate change projections over the world (Giorgi et al. 2009). In CORDEX-East Asia, which is the East Asia branch of the CORDEX framework, many studies predicting future temperature or precipitation have been carried out (Suh et al. 2012; Oh et al. 2013; Park et al. 2013; Lee and Hong 2014; Zou et al. 2014). However, only a few studies have examined tropical cyclone activities over the WNP using the CORDEX-East Asia experiment (Jin et al. 2015; Shen et al. 2016). Jin et al. (2015) evaluated TC activities over the WNP in five models [HadGEM3-RA, RegCM, Seoul National University Regional Climate Model (SNURCM), WRF, and Global/Regional Integrated Model system (GRIMs)] included in the CORDEX-East Asia project. They determined that four of the models, all except for HadGEM3-RA, have the capability of producing realistic TC activity compared with observation despite some systemic errors. The models also followed the interannual variability induced by ENSO. However, those studies only evaluated the present climate and did not analyze the future change in TC activity over the WNP.

In this study, the future changes and TC activity over the WNP under the representative concentration pathway (RCP) 8.5 scenario were projected using four models (RegCM, SNURCM, WRF, and GRIMs) that participated in the CORDEX-East Asia project. To examine future changes in the characteristics of TCs over the WNP, we analyzed the differences in genesis and track densities, intensity, and accumulated cyclone energy (ACE) between present climate and future climate. To measure the destructiveness of TCs, ACE is calculated by squaring the 6-hourly maximum wind speed. The ACE of a season is the sum of the ACEs for each TC and takes into account the number, strength, and lifetime of all TCs in the season. Therefore, the sensitivity of the ACE to the frequency, longevity, and intensity of TC is significantly large. There have been a number of studies to investigate the future changes in ACE for global basins. For example, Knutson et al. (2015) showed that four of the six major basins had a decreasing tendency of ACE in the future climate under the RCP4.5 scenario, whereas two (i.e., the eastern North Pacific and northern Indian Ocean basins) had an increasing tendency. Yamada et al. (2010) indicated that the ACE over the WNP tended to increase because of global warming, although lifetime and frequency were almost unchanged. In this study, we focus on the change in ACE for the extratropical WNP.

The regional climate models, data, and methodology, including the tracking of TCs, are described in section 2. In section 3, we evaluate the climatology of simulated TC activities and the large-scale conditions in the present-day simulation. The projected future changes in TC activity and the associated synoptic fields over the WNP are presented in section 4 . We also investigated the consistency of changes in synoptic fields in CMIP5. A summary of these results is provided in section 5 .

\section{Data and methodology}

\section{a. Data}

The TC best track data from the Regional Specialized Meteorological Centers (RSMC) Tokyo-Typhoon Center were obtained for the period of 1980-2005. The location where the intensity of each TC first become higher than $17 \mathrm{~m} \mathrm{~s}^{-1}$ (i.e., tropical storm intensity) was defined as the genesis point, therefore tropical storms and typhoons would be included as TCs. The analysis was focused on TCs that formed from June to November (JJASON), since most TCs over the WNP (around 85\% of the total annual TCs) tend to occur during the period. To evaluate the performance of the RCMs, simulated atmospheric fields were compared with ERA-Interim (Dee et al. 2011).

\section{b. CORDEX-East Asia models}

Under the climate projection framework for CORDEXEast Asia, four RCMs (Table 1) are nested within HadGEM2-AO to estimate future Asian regional climate. All of the RCMs are forced by HadGEM2-AO with a horizontal resolution of about $1.875^{\circ} \times 1.25^{\circ}$ and 
TABLE 1. The configurations of the RCMs used in this study.

\begin{tabular}{|c|c|c|c|c|}
\hline & $\operatorname{RegCM}$ & SNURCM & WRF & GRIMs \\
\hline Institute & $\begin{array}{l}\text { Kongju National } \\
\text { University }\end{array}$ & $\begin{array}{l}\text { Seoul National } \\
\text { University }\end{array}$ & $\begin{array}{l}\text { Seoul National } \\
\text { University }\end{array}$ & Yonsei University \\
\hline Dynamics framework & Hydrostatic & Nonhydrostatic & Nonhydrostatic & Hydrostatic \\
\hline Projection, resolution & $\begin{array}{l}\text { Lambert conformal, } \\
50 \mathrm{~km}\end{array}$ & $\begin{array}{l}\text { Lambert conformal, } \\
50 \mathrm{~km}\end{array}$ & $\begin{array}{l}\text { Lambert conformal, } \\
50 \mathrm{~km}\end{array}$ & Mercator, $50 \mathrm{~km}$ \\
\hline Vertical levels & 18 & 24 & 27 & 22 \\
\hline Convection & Emanuel (1991) & Kain (2004) & Kain (2004) & Hong and Pan (1998) \\
\hline PBL & Holtslag et al. (1990) & Hong et al. (2006) & Hong et al. (2006) & Hong et al. (2006) \\
\hline Spectral nudging & Yes (full wind nudging) & Yes (full wind nudging) & Yes (full wind nudging) & $\begin{array}{l}\text { Yes (rotational wind } \\
\text { nudging only) }\end{array}$ \\
\hline Reference & Giorgi et al. (2012) & Lee et al. (2004) & Skamarock et al. (2008) & Hong et al. (2013) \\
\hline
\end{tabular}

38 vertical levels (Baek et al. 2013). Sea surface temperature (SST) data from HadGEM2-AO are prescribed as the lower boundary of the RCMs. To decrease the systematic errors in long-term simulations, a spectral nudging technique is applied to all RCMs. The RCMs were performed over the CORDEX-East Asia domain with $\sim 50-\mathrm{km}$ horizontal resolution. Although the CORDEXEast Asia domain does not include the whole region of TC activities over the WNP, it covers major activity regions over the WNP. Thereby, the overall conclusion of this study will not change significantly, because future changes in most TC activities over the WNP are included in the domain.

The almost identical configurations (i.e., domain, resolution, driving data, and simulation period) allowed us to evaluate the performance of model fairly and diminish the systematic error of a single RCM in simulating TCs by constructing the multimodel ensemble. Under the CORDEX-East Asia framework, two periods are defined to assess the RCMs' abilities to reproduce present climate and estimate the future regional climate change under the RCP8.5 scenario: 1979-2005 for the present climate and 2006-50 for the future climate. In this study, simulated results during two periods representing the present (1980-2005) and future (2024-49) climates were analyzed. To investigate major TC activities over the WNP, the model output was converted to the analysis domain $\left(0^{\circ}-45^{\circ} \mathrm{N}, 100^{\circ}-160^{\circ} \mathrm{E}\right)$ with $0.5^{\circ}$ resolution (Fig. 1). Because the analysis domain is smaller compared with the entire WNP basin and the models can be significantly affected by the position of the domain boundary, simulated and observed TCs should be analyzed carefully (Landman et al. 2005; Camargo et al. 2007). In this study, we defined the genesis and track positions of observed TC coming from outside of the analysis domain as the first and subsequent positions after entering the boundaries of the analysis domain.

\section{c. Methods}

The TC detection and tracking methods employed in this study were similar to those in Jin et al. (2015), except for some thresholds: 1) a local minimum position of sea level pressure was the potential TC core, 2 ) the maximum wind at the surface was stronger than the wind speed threshold, 3 ) the maximum wind speed at $850 \mathrm{hPa}$ was larger than that at $300 \mathrm{hPa}, 4)$ the temperature deviations from the environment at three levels $(200,500$, and $850 \mathrm{hPa})$ were larger than the threshold of temperature anomaly, 5) the maximum value of $850-\mathrm{hPa}$ relative vorticity exceeded the threshold of vorticity, 6) the lifetime should be longer than 2 days, and 7) tracks were traced from the identified potential TCs. Here, the thresholds of wind, temperature anomaly,

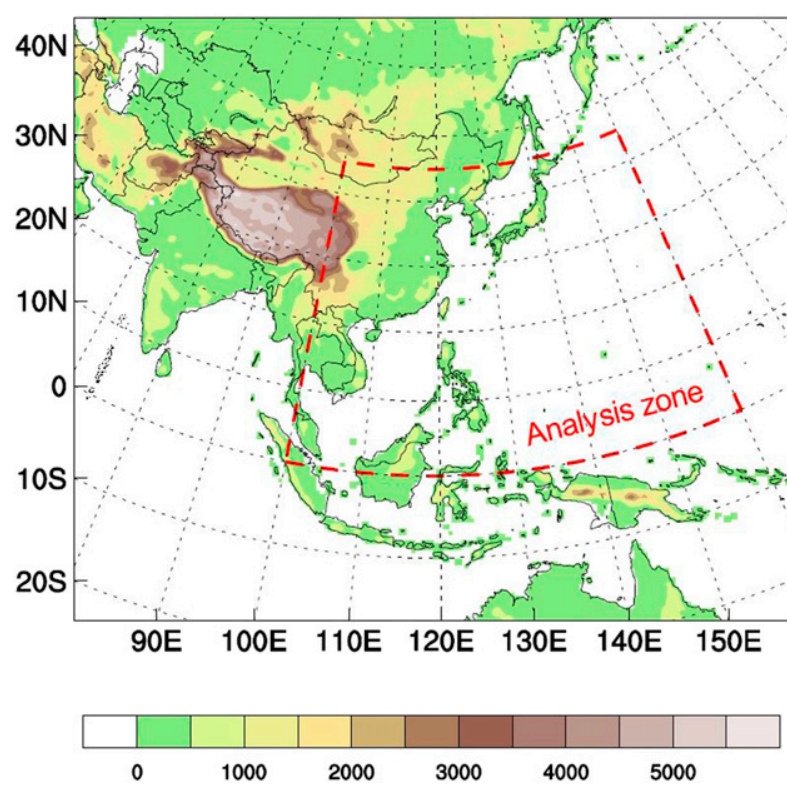

FIG. 1. The CORDEX-East Asia domain with topography (m) and western North Pacific area (dashed line). 
TABLE 2. Thresholds used for the relative vorticity, surface wind speed, and warm-core temperature for defining TCs in the WNP.

\begin{tabular}{lccrc}
\hline \hline & RegCM & SNURCM & WRF & GRIMs \\
\hline Vorticity $\left(10^{-5} \mathrm{~s}^{-1}\right)$ & 7.7 & 8.0 & 8.2 & 8.9 \\
Temperature $(\mathrm{K})$ & 1.3 & 1.5 & 1.0 & 1.6 \\
Wind speed $\left(\mathrm{m} \mathrm{s}^{-1}\right)$ & 16.1 & 17.0 & 15.5 & 16.8 \\
\hline
\end{tabular}

and vorticity were defined as model-dependent values, as suggested in Camargo and Zebiak (2002), to analyze the RCM's skill to reproduce TC activity fairly. Table 2 shows the three threshold values used for the four RCMs.

To diminish the uncertainty of a single RCM, the multimodel ensemble (MME) mean of four RCMs was constructed using the performance-based ensembleaveraging method proposed by Suh et al. (2012). The ensemble averaging from this method was calculated with different weightings using spatial correlation coefficients and root-mean-square errors (RMSEs) of TC genesis densities in the analysis area between observation and simulation. The MME mean had the best skill in simulating not only temperature and precipitation but also TC activity among the various ensemble methods (Suh et al. 2012; Jin et al. 2015). Here, the MME means of four RCMs in the historical and RCP8.5 scenario runs are referred to as RCM_HIST and RCM_RCP8.5, respectively.

TC genesis and track densities were computed by binning the longitude and latitude positions of the TC onto a grid box with $2.5^{\circ} \times 2.5^{\circ}$ resolution; this method has generally been applied to the binning of TC data (Kim et al. 2010; Ho et al. 2013). TC track density was calculated by binning 6-hourly TC locations into the corresponding grid boxes. The identical TC migrating within a grid box was counted only once.

To investigate the changes in TC destructiveness, we also calculated future changes in three variables for each year: minimum sea level pressure, maximum wind speed, and ACE.

\section{Climatology of TC activity in the historical run}

\section{a. TC genesis and track}

To evaluate the performances of RCMs in simulating TC activity over the WNP, spatial distributions of climatological seasonal TC genesis and track in RCM HIST were compared to those in the observation (Fig. 2). The locations of TC genesis in the observation are concentrated in the region between $5^{\circ}$ and $25^{\circ} \mathrm{N}$ with three local maxima: the Mariana Trench $\left(\sim 145^{\circ} \mathrm{E}\right)$, the western part of the Philippine Sea (PS; $\left.125^{\circ}-135^{\circ} \mathrm{E}\right)$, and the South China Sea (SCS; $\left.115^{\circ}-120^{\circ} \mathrm{E}\right)$. RCM_HIST tends to overestimate the TC formation over the SCS and the eastern boundary of the domain $\left(155^{\circ}-160^{\circ} \mathrm{E}\right)$ but to underestimate it over the western part of the PS (Figs. 2a,b). Although positive (negative) bias of TC genesis is present in the east and west (vicinity) of the observed climatological mean genesis position $\left(16.4^{\circ} \mathrm{N}, 136.1^{\circ} \mathrm{E}\right)$, the simulated genesis position $\left(16.3^{\circ} \mathrm{N}, 135.6^{\circ} \mathrm{E}\right)$ roughly corresponds to the observation. However, RCM_HIST has a slightly positive bias in simulating the number of TCs (18.5 in the observation vs 19.8 in RCM_HIST; see Table 3).

The observed tracks are concentrated in the western part of the PS, whereas the simulated tracks are dispersed into the SCS and the eastern part of the WNP. That is, RCM_HIST tends to underestimate track density over the western part of the PS and the East China Sea (ECS) but to overestimate it over the SCS and eastern part of the WNP (Figs. 2c,d). These biases of track density should be related to the nearby biases of genesis density (Figs. 2b,d). Naturally, the positive biases over the SCS and eastern part of the WNP are attributable to overestimated genesis therein. The negative bias over the ECS could be associated with the underestimated genesis frequency in the western part of the PS because TCs generated in the western part of the PS tend to move to the ECS along with the western boundary of the western North Pacific subtropical high (WNPSH) (Kim et al. 2012). These bias patterns have often been found in previous studies (Kim et al. 2015; Wu et al. 2014).

The systematic errors in the MME appear to be similar across all RCMs to a greater or lesser degree (not shown). This implies that the biases in the individual RCMs were not satisfactorily offset by combining the RCMs because the RCMs shared common biases induced by the single GCM (i.e., HadGEM2-AO). Nevertheless, the distributions of TC genesis and track in the MME (spatial correlations are 0.76 and 0.85 , respectively) still show good agreement with observation compared to those $(0.53-0.74$ and $0.73-0.85)$ in the individual RCMs included in the MME. This indicates that the MME can reduce the systematic errors of the RCMs somewhat, despite common biases existing because of the single GCM forcing. Therefore, more reliable future projections can be obtained from an MME.

\section{b. Large-scale environments}

The characteristics of WNP TC activity are associated with large-scale environments, such as the monsoon trough, vertical wind shear (VWS), and WNPSH. In the observation, TCs are mainly generated around the monsoon trough area (i.e., positive relative vorticity), which is derived from low-level cyclonic circulation, and a region of weak VWS (less than $10 \mathrm{~m} \mathrm{~s}^{-1}$ ), which is primarily modulated by zonal winds (Wu et al. 2012). After genesis, TCs in the tropics typically move 

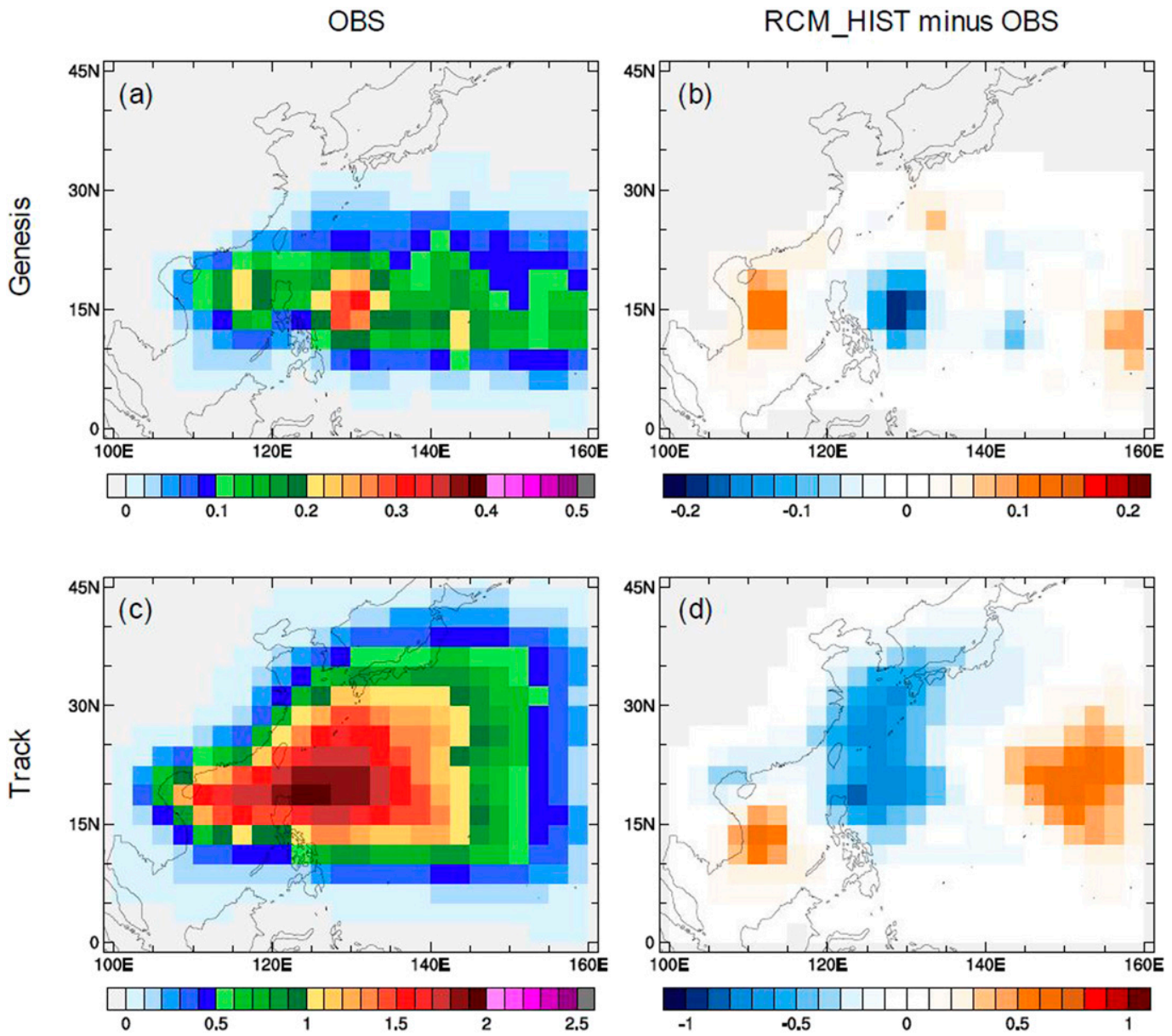

FIG. 2. Climatological mean of TC (a),(b) genesis and (c),(d) track density in (left) observation and (right) differences between RCM_HIST and observation for the period of 1980-2005.

westward along with the western boundary of the WNPSH, whereas TCs in the midlatitudes move eastward by strong VWS (i.e., upper-level westerly). Here, the WNPSH is defined as the deviation of geopotential height from the regional average over $0^{\circ}-30^{\circ} \mathrm{N}, 100^{\circ}-$ $160^{\circ} \mathrm{E}$ instead of the 5880 -gpm contour, because models substantially increase geopotential height in the future projection compared to the present-day simulation ( $\mathrm{He}$ et al. 2015; Wu et al. 2014).

Synoptic-scale variables in ERA-Interim and MME are analyzed in Fig. 3 to examine the reasons for the TC activity biases. In RCM_HIST, the monsoon trough is

TABLE 3. TC statistics for observations, RCM_HIST, and RCM_RCP8.5. Changes between the model results that are statistically significant at the $95 \%$ confidence level using a two-sided Student's $t$ test are shown in boldface. NTC and NTC_EAC indicate number of all TCs over the WNP and number of TCs moving to or developing in the East Asia coastal region, respectively.

\begin{tabular}{|c|c|c|c|c|c|}
\hline & \multirow[b]{2}{*}{ Obs } & \multicolumn{2}{|c|}{ RCM_HIST } & \multicolumn{2}{|r|}{ RCM_RCP8.5 } \\
\hline & & Mean & Bias $(\mathrm{RCM}-\mathrm{Obs})$ & Mean & Change (RCM_RCP8.5 - RCM_HIST) \\
\hline NTC & 18.5 & 19.7 & 1.2 & 20.7 & $+1.0(+5 \%)$ \\
\hline NTC_EAC & 8.6 & 5.8 & -2.8 & 6.7 & $+1.0(+17 \%)$ \\
\hline $\operatorname{ACE}\left(10^{4} \mathrm{~m}^{2} \mathrm{~s}^{-2} \mathrm{yr}^{-1}\right)$ & 46.8 & 24.5 & -22.3 & 29.1 & $+4.7(19 \%)$ \\
\hline Max wind speed $\left(\mathrm{m} \mathrm{s}^{-1}\right)$ & 37.9 & 27.1 & -10.8 & 28.3 & $+1.1(+4 \%)$ \\
\hline Lifetime (days) & 5.9 & 5.4 & -0.5 & 5.7 & +0.4 \\
\hline Longitude $\left({ }^{\circ} \mathrm{E}\right)$ & 136.1 & 135.6 & -0.4 & 135.4 & -0.3 \\
\hline Latitude $\left({ }^{\circ} \mathrm{N}\right)$ & 16.4 & 16.3 & -0.1 & 16.2 & -0.1 \\
\hline
\end{tabular}


OBS
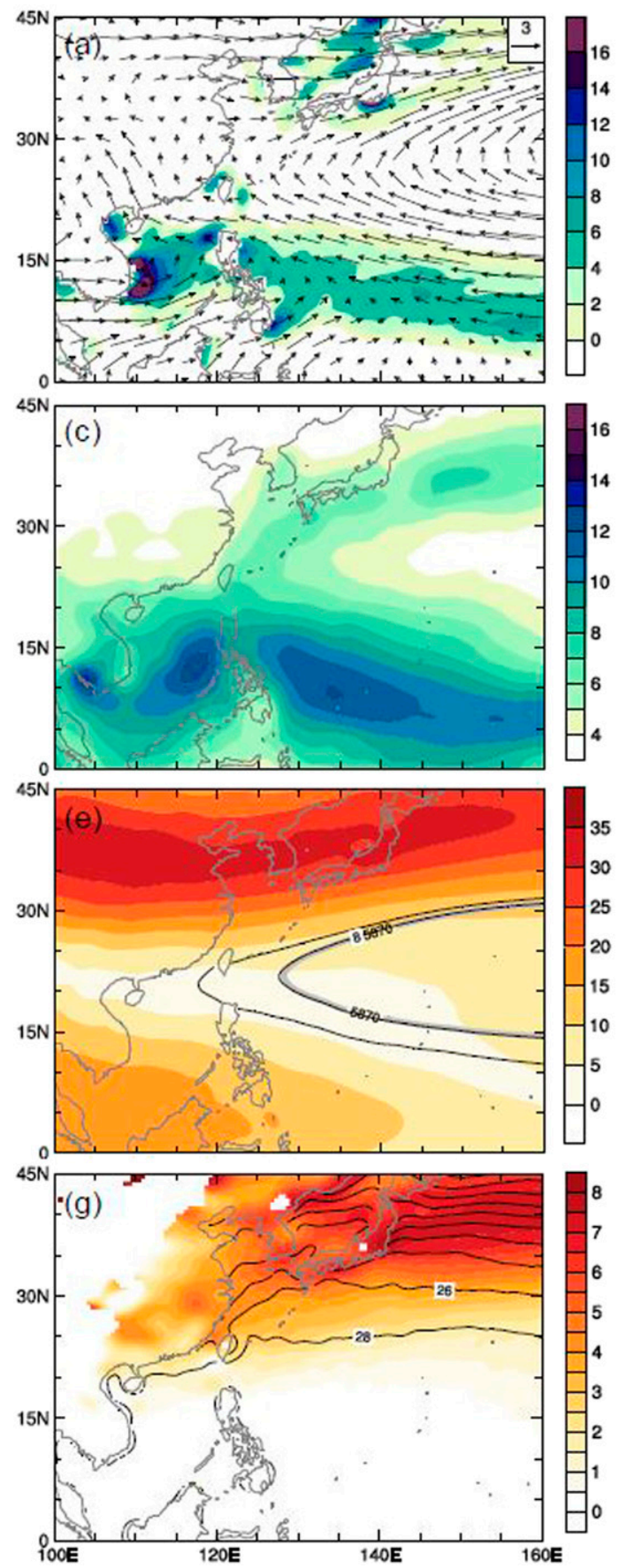

RCM_HIST minus OBS
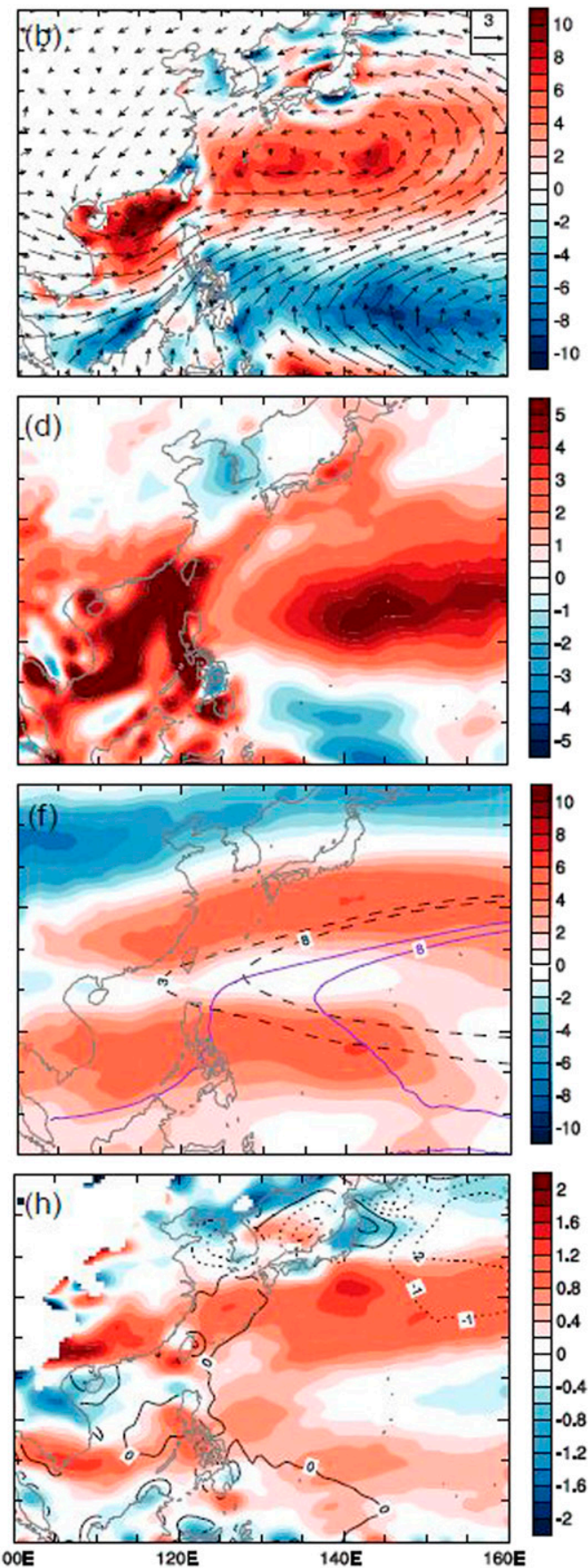

Fig. 3. As in Fig. 2, but for (a),(b) 850 -hPa relative vorticity $\left(10^{-5} \mathrm{~s}^{-1}\right.$; shading) and $850-\mathrm{hPa}$ wind $\left(\mathrm{m} \mathrm{s}^{-1}\right.$; vectors), (c),(d) precipitation $\left(\mathrm{mm} \mathrm{day}^{-1}\right)$, (e),(f) vertical wind shear $\left(\mathrm{m} \mathrm{s}^{-1}\right.$; shading) and 500-hPa eddy geopotential height (gpm; black solid and dashed contours for observations and purple solid contours for MME), and (g), (h) meridional 850 -hPa temperature gradient $\left(10^{-3}{ }^{\circ} \mathrm{C} \mathrm{km}^{-1}\right.$; shading) and sea surface temperature $\left({ }^{\circ} \mathrm{C}\right.$; contours). The observed 5870-gpm line is also plotted in (e). 
stronger in the SCS, ECS, and southern coast of Japan but weaker in the tropical WNP compared to that in the observation. These positive and negative biases of relative vorticity could arise from enhanced lower-level southwesterly flow associated with excessively overestimated precipitation (i.e., convective activity) in the subtropical region and SCS (Figs. 3b,d). This error presents in the HadGEM2-AO from Baek et al. (2013). The HadGEM2-AO from Baek et al. (2013) has a precipitation error over the SCS and southern coast of Japan of 2-4 mm day ${ }^{-1}$, while the MME of RCMs had enhanced error of $4 \mathrm{~mm} \mathrm{day}^{-1}$ or more. This indicates that the RCMs inherited synoptic characteristics from the HadGEM2-AO because of the spectral nudging and tended to overestimate convective activity sensitively over the SCS and subtropical WNP. The increasing convective activity over the subtropical WNP prohibits the westward expansion of the WNPSH, simulating more cyclonic circulation and lower geopotential height over the WNP in the regional climate simulation. These erroneous physical processes by RCMs can be associated with the uncoupled air-sea interaction as indicated by Cha et al. (2016). Figures $3 \mathrm{e}$ and $3 \mathrm{f}$ show the observed VWS and WNPSH and their difference from MME. The WNPSH from the observation and the MME is shown in Fig. $3 \mathrm{f}$ with a black dotted line and a solid purple line, respectively. In the MME, the VWS is overestimated below $30^{\circ} \mathrm{N}$, and the WNPSH is shifted southeastward compared to observation. This difference of WNPSH seems to be related to enhanced upper-level westerly flow at $30^{\circ} \mathrm{N}$ (not shown). In the PS, the underestimated TC formation is associated with the weakened monsoon trough and shifted WNPSH (Fig. 3f). In the SCS, the strengthened monsoon trough and local convective activity appear to increase the frequency of TC formation. In the eastern boundary, TC genesis may increase in the favorable confluent environment by the decreased easterly flow because of the weakened WNPSH. The prescribed SST and meridional temperature gradient of the observation and their difference from the MME are shown in Figs. $3 \mathrm{~g}$ and $3 \mathrm{~h}$, respectively. The prescribed SST has an extremely cold bias at $35^{\circ} \mathrm{N}$ (i.e., the northeastern boundary and the Yellow Sea) and warm biases in the ECS and south of Japan at $25^{\circ} \mathrm{N}$. This indicates that the meridional temperature gradient is overestimated at $30^{\circ} \mathrm{N}$ because of the differential warming between regions north and south of $30^{\circ} \mathrm{N}$. In turn, the increased temperature gradient results in significantly overestimated upper-level westerlies (i.e., VWS) there. The enhanced VWS in the midlatitude region seems to inhibit TCs that track toward East Asia coastal regions $\left(\mathrm{EAC} ; 20^{\circ}-35^{\circ} \mathrm{N}, 120^{\circ}-135^{\circ} \mathrm{E}\right)$. The zonal wind is proportional to the meridional temperature gradient in terms of thermal wind principle. This relationship is also shown in the reanalysis and historical run, respectively. In addition, the overestimated VWS over the subtropical WNP $\left(5^{\circ}-20^{\circ} \mathrm{N}\right)$ is associated with the exaggerated low-level southwesterly, which can be caused by uncoupled air-sea interaction within the RCM simulation as indicated by Cha and Lee (2009) and Cha et al. (2016). The overestimated and underestimated TC activities over the eastern boundary and EAC regions are also related to the eastward retreat of the WNPSH (Fig. 3f). Overall, our analysis of the historical run suggests that the MME of the four RCMs can be applied for the projection of future TC activities over the WNP because of the reasonable performances of simulating TCs.

\section{Projected changes in TC activity}

\section{a. TC genesis and track}

Figure 4 shows the spatial distributions of projected changes in TC track and genesis over the WNP. The quantitative changes in TC activities are summarized in Table 3. The WNP TC genesis frequency is 20.7 in the RCM_RCP8.5 run, which represents an insignificant increase of $5 \%$ compared to the frequency of 19.7 in the RCM_HIST run. The increases in TC genesis frequency occur in the eastern PS $\left(10^{\circ}-20^{\circ} \mathrm{N}, 130^{\circ}-150^{\circ} \mathrm{E}\right)$ and the southern SCS $\left(5^{\circ}-15^{\circ} \mathrm{N}, 110^{\circ}-120^{\circ} \mathrm{E}\right)$, east and west of the mean genesis location $\left(16.3^{\circ} \mathrm{N}, 136.1^{\circ} \mathrm{E}\right)$ (Figs. 4a,b). This results in no significant change in the mean genesis location. In addition, the structure of the changes shown here is not considered statistically robust because these changes are significant at $80 \%$ or lower levels. Overall, the future pattern of TC genesis tends to be shifted southeastward, far from the Asian continent. Many previous studies have consistently projected decreases in TC frequency (Knutson et al. 2015; Roberts et al. 2015), but other studies reported increases in TC frequency in the future (Emanuel 2013; Manganello et al. 2014). Three RCMs (i.e., RegCM, WRF, and GRIMs) simulated consistent increasing genesis density over the southern SCS and eastern PS. WRF in particular simulated an increasing trend of TC genesis density over most areas. On the other hand, SNURCM reproduced the decreasing signal over the northern SCS and northern PS (not shown).

Although TC genesis frequency increases slightly, the corresponding ACE shows a significant increase $(+19.0 \%)$ in the RCM_RCP8.5 run. It is followed by individual TC events with longer lifetimes $(+6.6 \%)$ and higher maximum wind speed $(+4.1 \%)$ compared to those in the historical run. These results are consistent with previous studies (Manganello et al. 2014; Zhang 

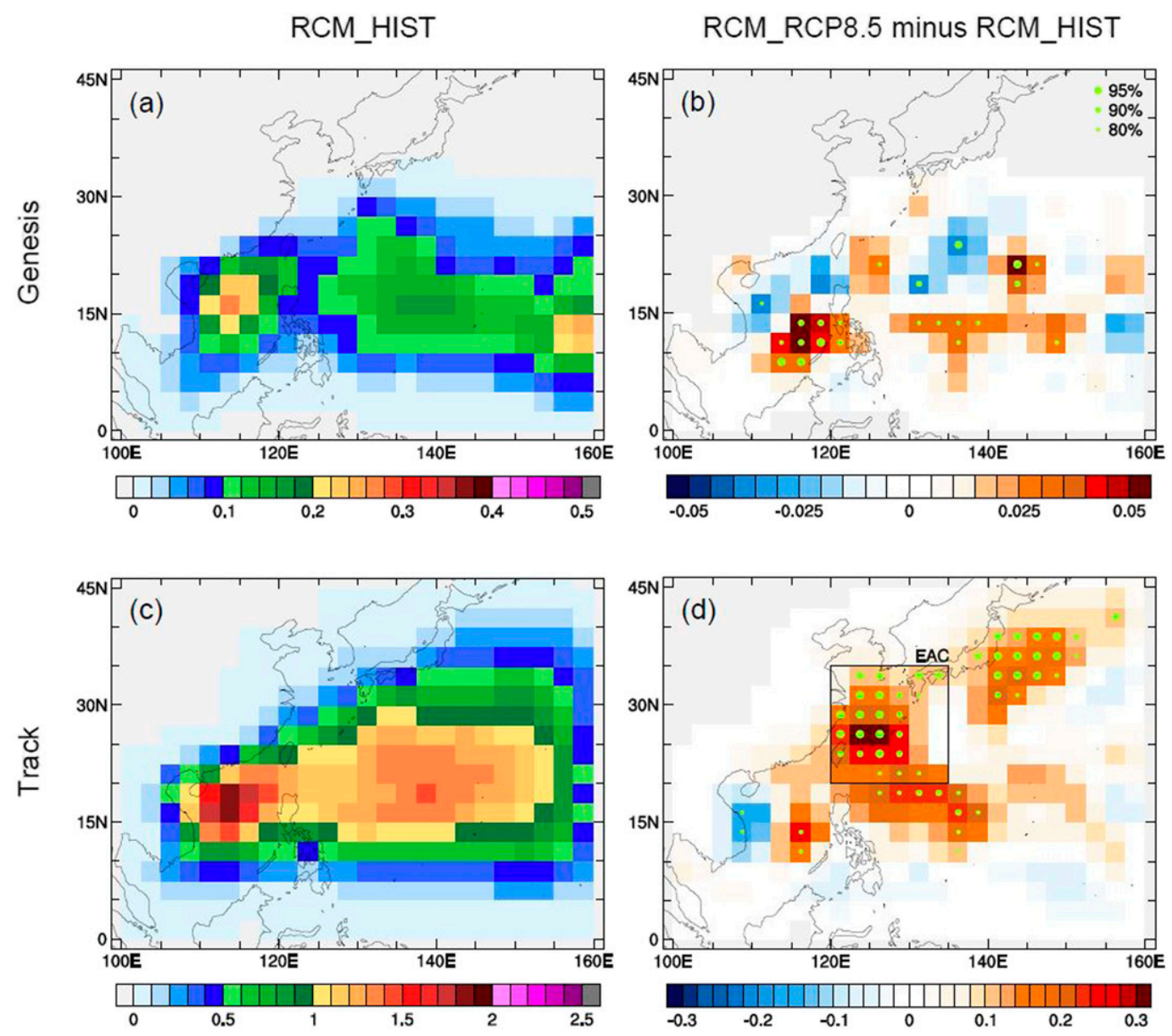

FIG. 4. Climatological mean of TC (a),(b) genesis and (c),(d) track density in (left) the historical simulation (1980-2005) and (right) differences between the RCP8.5 future scenario (2024-49) and the historical simulation. Green dots indicate that the differences are significant at the $80 \%, 90 \%$, and $95 \%$ confidence level based on a Student's $t$ test [see legend in (b)].

et al. 2016). These characteristics are also associated with a robust increase in TC track density over the PS, ECS, and region southeast of Japan (Fig. 4d). Especially, the number of TCs entering the EAC $\left(20^{\circ}-35^{\circ} \mathrm{N}, 120^{\circ}-\right.$ $\left.135^{\circ} \mathrm{E}\right)$ is increased significantly $(+17 \%)$. All four ensemble members consistently simulate the change in track density over the EAC. The increasing track over the midlatitudes is robust in RegCM, SNURCM, and GRIMs, but it is relatively weak in WRF (not shown). Such a change implies an increase in TCs making landfall over the EAC region. The patterns of track changes and the circumstance of the ocean southeast of Japan are similar to those shown in $\mathrm{Tu}$ et al. (2009) and Emanuel (2013), respectively.

The number of TCs moving to or developing in the EAC region (NTC_EAC) and the ACE for all TCs over the WNP increase robustly from 1980 to 2049 (Fig. 5). The frequency of all TCs over the WNP (NTC) hardly increases $\left[+0.9 \%(10 \mathrm{yr})^{-1}\right]$ during 70 years, whereas the NTC_EAC and ACE tend to increase with similar rates $\left[+3.5 \%\right.$ and $+3.0 \%(10 \mathrm{yr})^{-1}$, respectively]. This suggests that the increasing lifetime and maximum

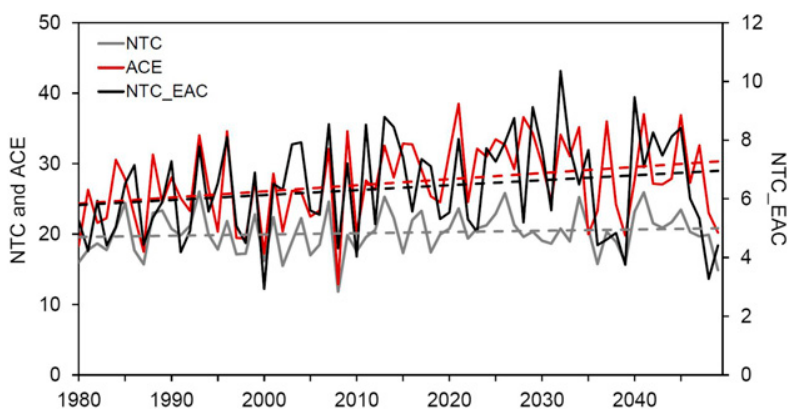

FIG. 5. Annual number of TC geneses (solid gray), number of TCs entering the EAC region (solid black), and ACE (solid red; $10^{4} \mathrm{~m}^{2} \mathrm{~s}^{-2}$ ). Dashed lines indicate the linear trends. 
TABLE 4. ACE, mean intensity, total number of TCs, and mean duration of TCs that are moving northward over $25^{\circ} \mathrm{N}$.

\begin{tabular}{|c|c|c|c|}
\hline & RCM_HIST & RCM_RCP8.5 & Change \\
\hline $\operatorname{ACE}\left(10^{4} \mathrm{~m}^{2} \mathrm{~s}^{-2} \mathrm{yr}^{-1}\right)$ & 4.4 & 6.5 & $2.0(+45.9 \%)$ \\
\hline Mean intensity $\left(\mathrm{m} \mathrm{s}^{-1} \mathrm{yr}^{-1}\right)$ & 22.7 & 23.8 & $1.1(+4.8 \%)$ \\
\hline NTC $\left(\mathrm{yr}^{-1}\right)$ & 8.7 & 9.4 & $0.7(+8.0 \%)$ \\
\hline Mean duration (days $\mathrm{yr}^{-1}$ ) & 2.22 & 2.65 & $0.44(+19.7 \%)$ \\
\hline
\end{tabular}

wind speed lead to an increase in ACE, considering that the seasonal ACE is affected by three values: the number of seasonal TCs, the lifetime, and the maximum wind speed. In addition, it is noteworthy that the interannual variability of the ACE of all TCs over the WNP is substantially correlated with that of the NTC_ EAC, indicating that ACE can be increased because of the change in the NTC_EAC.

As shown in Figs. 4d and 5, the possibility of TC landfall in the midlatitudes could be increased. To investigate the vulnerability over the East Asian continent, the changes in the frequency, ACE, mean maximum wind velocity, and mean duration of TCs moving northward over $25^{\circ} \mathrm{N}$ between the future climate and the present climate are depicted in Table 4 . Those were calculated only after TCs had passed through $25^{\circ} \mathrm{N}$. In the future climate, the mean intensity and NTC increase by $4.8 \%$ and $8.0 \%$, respectively, but these two changes are not significant. However, mean duration increases by $19.7 \%$, which leads to the growth of ACE at a significant level. This means that the northward extension of the TC track to the midlatitudes is mainly due to the increase of TC duration. Stronger TCs will be able to approach to the midlatitudes with their longer duration in the future. Thus, the vulnerability to TC damage for East Asian megacities such as Shanghai $\left(31.2^{\circ} \mathrm{N}\right)$, Seoul $\left(37.5^{\circ} \mathrm{N}\right)$, and Tokyo $\left(35.7^{\circ} \mathrm{N}\right)$ could be increased in the mid-twenty-first century.

\section{b. Large-scale environments}

To understand the possible causes for the future changes in TC track and genesis, we examined projected changes in large-scale environments induced by climate change (Fig. 6). In RCM_RCP8.5, slightly increasing TC genesis frequencies over the tropical WNP and Mariana Trench are associated with a slightly enhanced monsoon trough, weakened VWS, and diminished WNPSH there (Figs. 4b, 6b). However, these favorable conditions for TC genesis are not enhanced sufficiently to overcome relatively weak SST warming pattern in the tropical WNP derived from HadGEM2-AO (Fig. 6h). Spatial patterns of SST can cause substantial variations in projected future changes in TC activities over the WNP (Murakami et al. 2012). Especially, tropical SST variations (e.g., ENSO) have modulated TC activity over the
WNP (e.g., Jin et al. 2013). SST warming occurs over the northern off-equatorial central Pacific, but it is ineffective in modulating the monsoon trough and VWS because it is outside the model domain (not shown). Compared to that of the tropical region, midlatitude SST warming is larger, with maximum warming at $40^{\circ} \mathrm{N}$. This differential warming indicates that the meridional temperature gradient decreases around $30^{\circ} \mathrm{N}$ (Fig. 6h). In turn, the decreasing meridional temperature gradient would result in significantly reduced VWS (i.e., upperlevel westerly flow) in the midlatitudes and could provide a favorable condition for TC passage through the reduced VWS region near the EAC and southeast of Japan (Figs. 4d, 6f). Interestingly, the increased TC track induced by weakened VWS in the EAC region is consistent with the results from both a TC projection study (Manganello et al. 2014) and also an observational study (Tu et al. 2009). Additionally, the weakened VWS could be linked to relatively less warming over the Maritime Continent (not shown). Hong and Ahn (2015) showed that upper-level westerly flow in the midlatitudes could be decreased because of the angular momentum conservation according to the weakening of the poleward upper-level winds induced by decreasing vertical motions in the rising branch of Hadley circulations centered on the Maritime Continent. In addition to changes in meridional temperature gradient, more increased SST over the midlatitudes than the subtropics can result in the northward extension of TCs over the WNP, because warmer SST is able to enhance TC development or delay TC decay by providing more energy to TCs (Figs. 4d, 6h).

The enhanced future TC activities over the EAC region is associated with the decrease in VWS at the midlatitudes as the meridional temperature gradient decreases in the HadGEM2-AO. Meanwhile, as analyzed in the historical run, the patterns of systemic error of the four individual RCMs are similar to that of the MME (not shown). This may decrease the reliability of the future projection by RCMs because RCMs have a fundamental difficulty of completely reducing the error inherited from HadGEM2-AO. Therefore, some studies for future projection of TCs have used multi-GCM ensemble SST data to resolve this problem (Murakami et al. 2011b; Wu et al. 2014). To resolve this issue, we 


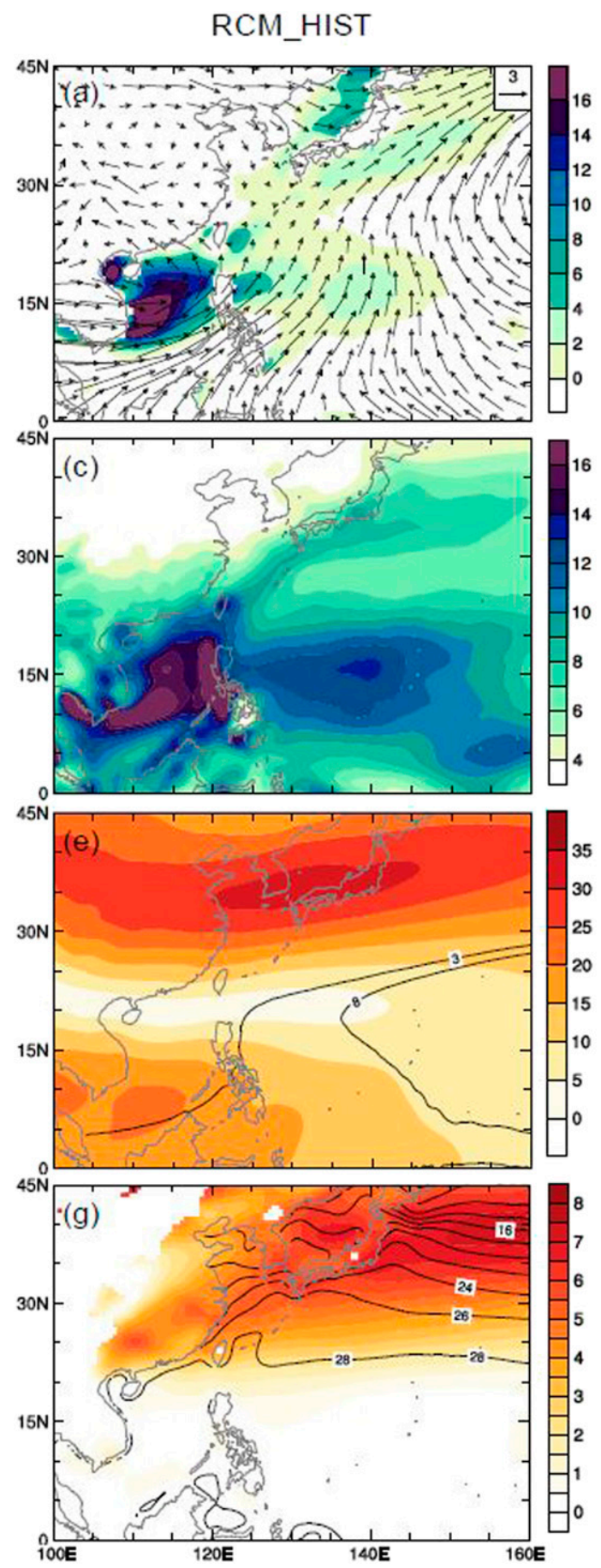

RCM_RCP8.5 minus RCM_HIST
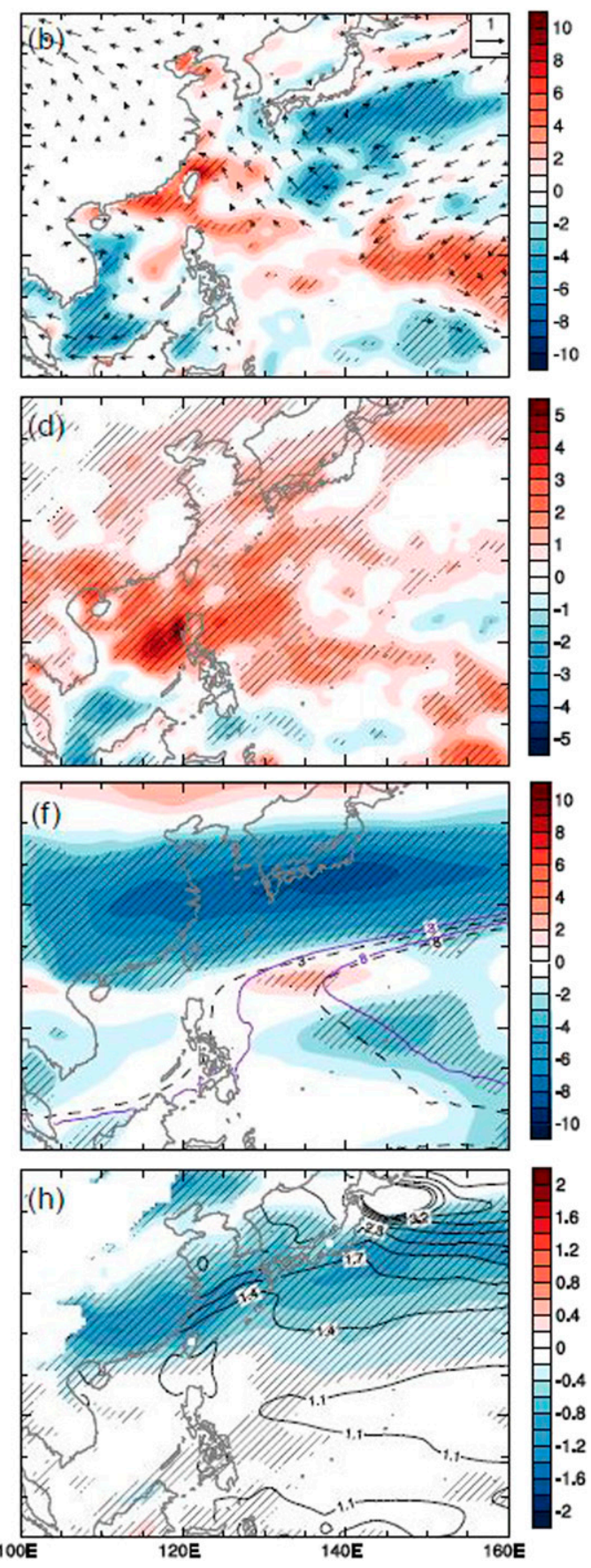

FIG. 6. As in Fig. 4, but for (a),(b) $850-\mathrm{hPa}$ relative vorticity $\left(10^{-5} \mathrm{~s}^{-1}\right.$; shading) and $850-\mathrm{hPa}$ wind $\left(\mathrm{m} \mathrm{s}^{-1}\right.$; vectors), (c),(d) precipitation $\left(\mathrm{mm} \mathrm{day}^{-1}\right)$, (e),(f) vertical wind shear $\left(\mathrm{m} \mathrm{s}^{-1}\right.$; shading) and 500-hPa eddy geopotential height (gpm; black solid and dashed contours for observations and purple solid contours for MME), and (g),(h) meridional $850-\mathrm{hPa}$ temperature gradient $\left(10^{-3}{ }^{\circ} \mathrm{C} \mathrm{km}^{-1}\right.$; shading) and sea surface temperature $\left({ }^{\circ} \mathrm{C}\right.$; contours). Diagonal shading indicates that the differences are significant at the $80 \%$ confidence level based on a Student's $t$ test. 


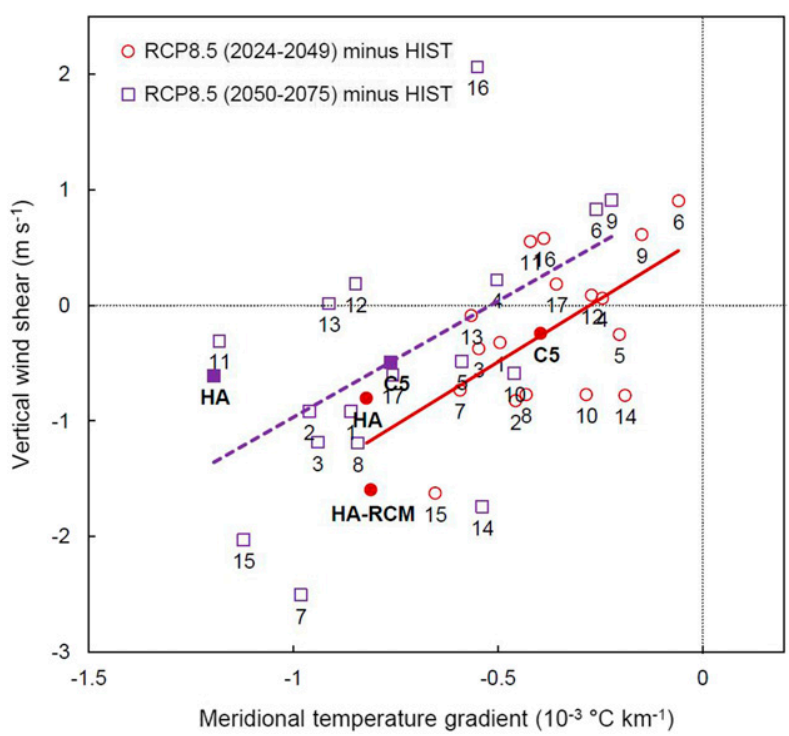

FIG. 7. Scatter diagram for the changes in vertical wind shear as a function of meridional temperature gradient averaged over $25^{\circ}-40^{\circ} \mathrm{N}, 120^{\circ}-145^{\circ} \mathrm{E}$ under RCP8.5 for the periods of $2024-49$ (red circles) and 2050-75 (purple squares) compared to the historical run (1980-2005). Each numbered point (C5, HA, and HA-RCM) indicates models marked in Table 5 (the ensemble of these 17 models, and HadGEM2-AO and the MME used in the present study, respectively). The regression lines for periods of 2024-49 (red solid line) and 2050-75 (purple dashed line) are also drawn.

investigated VWS and meridional temperature gradient as simulated by other GCMs in CMIP5. Figure 7 shows a scatter diagram for the changes in VWS as a function of the meridional temperature gradient averaged over $25^{\circ}$ $40^{\circ} \mathrm{N}, 120^{\circ}-145^{\circ} \mathrm{E}$ from $18 \mathrm{CMIP} 5 \mathrm{GCMs}$, including HadGEM2-AO and their MME, and the MME of the four RCMs employed in this study. The CMIP5 models are listed in Table 5. The MME of the four RCMs captures a positive correlation between VWS and meridional SST gradient that is enhanced compared with those in the GCMs. As the temperature gradient decreases in all GCMs, most of the models simulate weakened VWS, even if seven models simulate enhanced VWS in the near future (2024-49). This implies that the HadGEM2-AO has the capability to simulate large-scale fields similar to the MME of CMIP5 GCMs. In addition, this relationship tends to become more substantial in the far future (2050-75) than in the near future. HadGEM2-AO maintains a consistent difference pattern with the MME of CMIP5 in the far future, although it intensifies the meridional temperature gradient. Therefore, it becomes more reliable that TC activity over the EAC region could be enhanced by the decreased temperature gradient and weakened VWS therein in the RCP8.5 scenario.
TABLE 5. The 17 CMIP5 models used to calculate VWS and meridional temperature gradient. Numbers in the right column correspond to labeled symbols in Figs. 7 and 8.

\begin{tabular}{|c|c|c|}
\hline Model name & Modeling group & No. \\
\hline ACCESS1.0 & $\begin{array}{l}\text { Commonwealth Scientific and Industrial } \\
\text { Research Organization and Bureau of } \\
\text { Meteorology }\end{array}$ & 1 \\
\hline BNU-ESM & $\begin{array}{l}\text { College of Global Change and Earth } \\
\text { System Science, Beijing Normal } \\
\text { University }\end{array}$ & 2 \\
\hline CanESM2 & $\begin{array}{l}\text { Canadian Centre for Climate Modeling } \\
\text { and Analysis }\end{array}$ & 3 \\
\hline CESM1-BGC & $\begin{array}{l}\text { National Center for Atmospheric } \\
\text { Research }\end{array}$ & 4 \\
\hline CNRM-CM5 & $\begin{array}{l}\text { Centre National de Recherches } \\
\text { Météorologiques/Centre Européen de } \\
\text { Recherche et Formation Avancée en } \\
\text { Calcul Scientifique }\end{array}$ & 5 \\
\hline CSIRO Mk3.6.0 & $\begin{array}{l}\text { Commonwealth Scientific and Industrial } \\
\text { Research Organization and } \\
\text { Queensland Climate Change Centre } \\
\text { of Excellence }\end{array}$ & 6 \\
\hline FGOALS-g2 & $\begin{array}{l}\text { LASG, Institute of Atmospheric } \\
\text { Physics, Chinese Academy of } \\
\text { Sciences and CESS, Tsinghua } \\
\text { University }\end{array}$ & 7 \\
\hline GFDL CM3 & $\begin{array}{l}\text { NOAA/Geophysical Fluid Dynamics } \\
\text { Laboratory }\end{array}$ & 8 \\
\hline GFDL-ESM2M & $\begin{array}{l}\text { NOAA/Geophysical Fluid Dynamics } \\
\text { Laboratory }\end{array}$ & 9 \\
\hline GISS-E2-R & $\begin{array}{l}\text { NASA Goddard Institute for Space } \\
\text { Studies }\end{array}$ & 10 \\
\hline HadGEM2-CC & Met Office Hadley Center & 11 \\
\hline HadGEM2-ES & Met Office Hadley Center & 12 \\
\hline IPSL-CM5A-LR & L'Institut Pierre Simon Laplace & 13 \\
\hline MIROC5 & $\begin{array}{l}\text { Japan Agency for Marine-Earth Science } \\
\text { and Technology, Atmosphere and } \\
\text { Ocean Research Institute (University } \\
\text { of Tokyo), and National Institute for } \\
\text { Environmental Studies }\end{array}$ & 14 \\
\hline MIROC-ESM & $\begin{array}{l}\text { Japan Agency for Marine-Earth Science } \\
\text { and Technology, Atmosphere and } \\
\text { Ocean Research Institute (University } \\
\text { of Tokyo), and National Institute for } \\
\text { Environmental Studies }\end{array}$ & 15 \\
\hline MPI-ESM-LR & Max Planck Institute for Meteorology & 16 \\
\hline NorESM1-M & Norwegian Climate Centre & 17 \\
\hline
\end{tabular}

As analyzed in Figs. 6 and 7, increasing SST over the extratropical WNP can lead to decreasing vertical wind shear over midlatitudes in the future climate. Furthermore, increased SST provides more energy to TCs entering the midlatitudes; therefore, it affects not only TC intensity but also TC lifetime. Similar to Fig. 7, changes in SST over $25^{\circ}-40^{\circ} \mathrm{N}, 120^{\circ}-145^{\circ} \mathrm{E}$ from CMIP5 GCMs during the periods of 2024-49 and 2050-75 compared to the historical run (1980-2005) are illustrated in Fig. 8. All CMIP5 models simulate warmer SST than the 


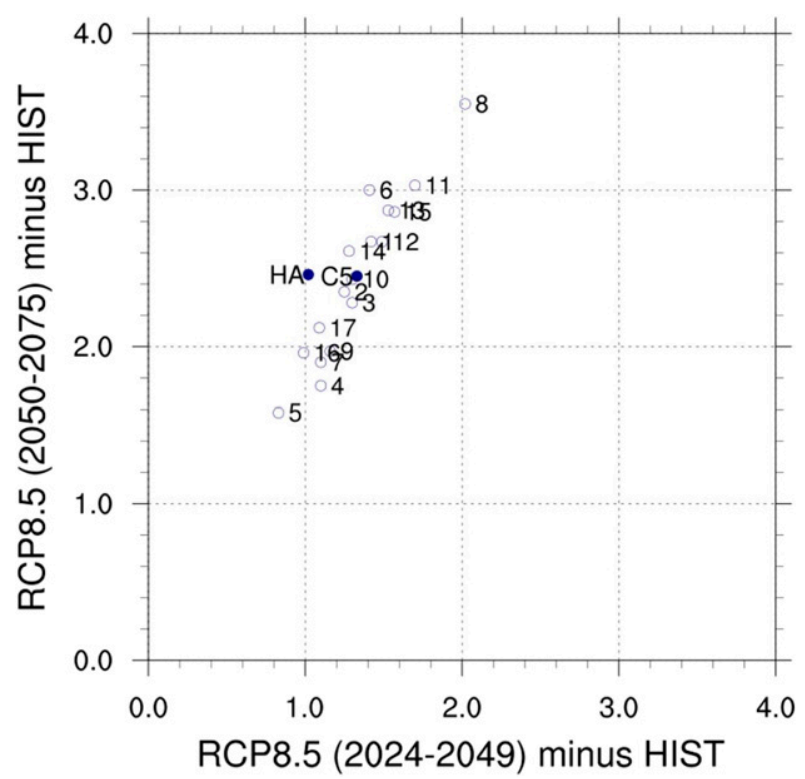

FIG. 8. Scatter diagram for the sea surface temperature change over $25^{\circ}-40^{\circ} \mathrm{N}, 120^{\circ}-145^{\circ} \mathrm{E}$ under RCP8.5 for the periods of 2024-49 and 2050-75 compared to the historical run (1980-2005). Each numbered point ( $\mathrm{C} 5$ and HA) indicates models marked in Table 5 (the ensemble of these 17 models and HadGEM2-AO, respectively).

historical run and an increasing trend of SST in the far future (2050-75) that is larger than that in the near future (2024-49). In particular, the point of HadGEM2-AO is located close to the ensemble of CMIP5. This provides confidence that future changes in SST can increase TC activity in the midlatitudes. Finally, weakened VWS as well as increased SST over the midlatitudes leads to increasing lifetime of TCs. Therefore, ACE there increases significantly by $45.9 \%$.

Furthermore, the future change in TC activity may be related to a mass flux as well as VWS and SST. The regions with increasing upward mass flux are consistent with those with prominently increasing precipitation in Fig. 6d (not shown). Also, the SCS and the western part of the PS with increasing upward mass flux are similar to the regions with increasing TC genesis in Fig. 4b. This indicates that increasing TC formation over the WNP can be related to the changes in upward mass flux and precipitation. However, the result of our study that the frequency of TC formation over the WNP increases in the future is different from others showing the decreasing TC frequency such as Sugi et al. (2012). This might be associated with the limitations of this study, such as one GCM forcing data and analysis period for the mid-twenty-first century when the global warming tendency is not prominent compared with the late twenty-first century.

\section{Conclusions and discussion}

Simulation of the present (1980-2005; historical) and projected (2026-49; RCP8.5) WNP TC activity was conducted using four $50-\mathrm{km}$ RCMs. The simulated climatological mean TC activity for the present climate shows many characteristics similar to observations, such as the seasonal features of TC genesis and tracks. The spatial distributions of the climatological-mean observed TC genesis tracks were realistically captured in the historical simulation, although systematic biases were found. The future (2024-49) projections indicated the insignificant change in the total number of TC geneses $(+5 \%)$, especially at lower latitudes (i.e., the eastern PS and southern SCS), and a robust increase in track density over EAC regions $(+17 \%)$. The enhanced TC activity over EAC regions is mainly related to vertical wind shear weakened by reduced meridional temperature gradient and increased SST at midlatitudes.

Other major changes in future TC activities over the WNP are associated with the ACE and intensity. The future ACE of total TCs shows a significant increase because individual TCs have a longer lifetime and higher maximum wind speed compared to those in the historical run. Although the change in the total number of TCs is not very large, the regions affected by the TCs are changed as TC intensity increases, especially in midlatitudes. This could affect future disaster management in East Asian nations. The ACE of TCs moving above $25^{\circ} \mathrm{N}$ increases by $45.9 \%$ in the future climate because of the extension of TC lifetime. This indicates that the probability of intense TC landfall at East Asian megacities could be increased in the future climate (Mei and Xie 2016).

VWS as a function of the meridional temperature gradient of HadGEM2-AO was compared with the 17 CMIP5 model ensemble. We addressed the change in VWS over the midlatitudes rather than low latitudes. The VWS in midlatitude can be determined by the upper-level westerly because of stronger wind speed; therefore, it tends to be proportional to meridional temperature gradient. VWS and meridional temperature gradient show a positive correlation between them and a decreasing trend in future climate. In particular, the decreasing trend is more enhanced in the late twentyfirst century (2050-75) than in the mid-twenty-first century (2024-49). HadGEM2-AO maintains a pattern of SST change to that of the CMIP5 ensemble in the late twenty-first century, which means that HadGEM2-AO properly projects the future change of meridional temperature gradient and VWS over midlatitudes. Also, a consistent increasing signal is revealed for SST. Nevertheless, the results are hardly representative of the future 
changes in the TC activities over the WNP, because this study is based on the dynamically downscaled results forced by not multi-GCMs but HadGEM2-AO.

RCMs with $50-\mathrm{km}$ horizontal resolution had a limitation to simulate realistic TC intensity because TC intensity is related to the core dynamics within $\sim 100-\mathrm{km}$ radius from TC center. For example, Jin et al. (2015) showed that RCMs with $50-\mathrm{km}$ horizontal resolution tended to underestimate TC intensity and could not capture strong TC intensity above $50 \mathrm{~m} \mathrm{~s}^{-1}$. In this study, therefore, the ACE index calculated could be affected by the underestimated TC intensity. For more realistic estimation of the ACE index, RCMs with higher resolution are needed. In addition, the future changes in TC activities seem to be significantly dependent on the spatial distribution of future SST; therefore, it is necessary to conduct ensemble projections by multi-GCMs and multi-RCMs to produce a SST spatial pattern within the range of acceptability. If the impacts of large-scale model biases are large, perturbation runs can be good alternatives, and they are well known as relatively easy ways to get robust results on TC changes. Knutson et al. (2015) explore climate change scenarios with RCM by perturbing the reanalysis input with climate modelprojected changes. We also plan to develop a model to predict the destructiveness of TCs using the statistical relationship between TC activities and associated damages.

In future work, we intend to examine the change in TC activities under two warming scenarios (RCP4.5 and RCP8.5) compared with the results of historical runs using the multi-RCMs ensemble evaluated in this study. Moreover, to make the future projection of TC intensity more reliable, the resolution of the RCMs will be increased as far as computing resources permit over multidecadal time scales. In addition, the physical processes (e.g., surface momentum flux parameterization and convective parameterization) and the spectral nudging should be improved for the advanced simulation of TCs.

Acknowledgments. This work was funded by the Korea Meteorological Administration Research and Development Program under Grant KMI (KMI201801211).

\section{REFERENCES}

Baek, H.-J., and Coauthors, 2013: Climate change in the 21st century simulated by HadGEM2-AO under representative concentration pathways. Asia-Pac. J. Atmos. Sci., 49, 603-618, https://doi.org/10.1007/s13143-013-0053-7.

Bender, M. A., T. R. Knutson, R. E. Tuleya, J. J. Sirutis, G. A. Vecchi, S. T. Garner, and I. M. Held, 2010: Modeled impact of anthropogenic warming on the frequency of intense
Atlantic hurricanes. Science, 327, 454-458, https://doi.org/ 10.1126/science.1180568.

Bengtsson, L., H. Böttger, and M. Kanamitsu, 1982: Simulation of hurricane-type vortices in a general circulation model. Tellus, 34, 440-457, https://doi.org/10.3402/tellusa.v34i5.10830.

— K. Kodges, and M. Esch, 2007: Tropical cyclones in a T159 resolution global climate model: Comparison with observations and re-analyses. Tellus, 59A, 396-416, https://doi.org/ 10.1111/j.1600-0870.2007.00236.x.

Camargo, S. J., 2013: Global and regional aspects of tropical cyclone activity in the CMIP5 models. J. Climate, 26, 9880-9902, https://doi.org/10.1175/JCLI-D-12-00549.1.

, and S. E. Zebiak, 2002: Improving the detection and tracking of tropical cyclones in atmospheric general circulation models. Wea. Forecasting, 17, 1152-1162, https://doi.org/10.1175/15200434(2002)017<1152:ITDATO>2.0.CO;2.

, H. Li, and L. Sun, 2007: Feasibility study for downscaling seasonal tropical cyclone activity using the NCEP regional spectral model. Int. J. Climatol., 27, 311-325, https://doi.org/10.1002/joc.1400.

Cha, D.-H., and D.-K. Lee, 2009: Reduction of systematic errors in regional climate simulations of the summer monsoon over East Asia and the western North Pacific by applying the spectral nudging technique. J. Geophys. Res., 114, D14108, https://doi.org/10.1029/2008JD011176.

, C. S. Jin, J. H. Moon, and D. K. Lee, 2016: Improvement of regional climate simulation of East Asian summer monsoon by coupled air-sea interaction and large-scale nudging. Int. J. Climatol., 36, 334-345, https://doi.org/10.1002/joc.4349.

Dee, D. P., and Coauthors, 2011: The ERA-Interim reanalysis: Configuration and performance of the data assimilation system. Quart. J. Roy. Meteor. Soc., 137, 553-597, https://doi.org/10.1002/qj.828.

Emanuel, K. A., 1991: A scheme for representing cumulus convection in large-scale models. J. Atmos. Sci., 48, 2313-2335, https:// doi.org/10.1175/1520-0469(1991)048<2313:ASFRCC >2.0.CO;2. 2013: Downscaling CMIP5 climate models shows increased tropical cyclone activity over the 21st century. Proc. Natl. Acad. Sci. USA, 110, 12 219-12224, https://doi.org/10.1073/ pnas.1301293110.

—, R. Sundararajan, and J. Williams, 2008: Hurricanes and global warming: Results from downscaling IPCC AR4 simulations. Bull. Amer. Meteor. Soc., 89, 347-368, https://doi.org/ 10.1175/BAMS-89-3-347.

Giorgi, F., C. Jones, and G. R. Asrar, 2009: Addressing climate information needs at the regional level: The CORDEX framework. WMO Bull, 58, 175-183.

—_, and Coauthors, 2012: RegCM4: Model description and preliminary tests over multiple CORDEX domains. Climate Res., 52, 7-29, https://doi.org/10.3354/cr01018.

Hasegawa, A., and S. Emori, 2005: Tropical cyclones and associated precipitation over the western North Pacific: T106 atmospheric GCM simulation for present-day and doubled $\mathrm{CO}_{2}$ climates. SOLA, 1, 145-148, https://doi.org/10.2151/sola.2005-038.

He, C., T. Zhou, A. Lin, B. Wu, D. Gu, C. Li, and B. Zheng, 2015: Enhanced or weakened western North Pacific subtropical high under global warming? Sci. Rep., 5, 16771, https://doi.org/ 10.1038/srep16771.

Ho, C. H., J. H. Kim, H. S. Kim, W. Choi, M. H. Lee, H. D. Yoo, T. R. Kim, and S. Park, 2013: Technical note on a trackpattern-based model for predicting seasonal tropical cyclone activity over the western North Pacific. Adv. Atmos. Sci., 30, 1260-1274, https://doi.org/10.1007/s00376-013-2237-6.

Holtslag, A. A. M., E. I. F. Debruijn, and H. L. Pan, 1990: A highresolution air-mass transformation model for short-range 
weather forecasting. Mon. Wea. Rev., 118, 1561-1575, https:// doi.org/10.1175/1520-0493(1990)118<1561:AHRAMT>2.0.CO;2.

Hong, J.-Y., and J.-B. Ahn, 2015: Changes of early summer precipitation in the Korean Peninsula and nearby regions based on RCP simulations. J. Climate, 28, 3557-3578, https://doi.org/ 10.1175/JCLI-D-14-00504.1.

Hong, S. Y., and H. L. Pan, 1998: Convective trigger function for a mass-flux cumulus parameterization scheme. Mon. Wea. Rev., 126, 2599-2620, https://doi.org/10.1175/1520-0493(1998)126<2599: CTFFAM $>2.0 . \mathrm{CO} ; 2$.

—, Y. Noh, and J. Dudhia, 2006: A new vertical diffusion package with an explicit treatment of entrainment processes. Mon. Wea. Rev., 134, 2318-2341, https://doi.org/10.1175/MWR3199.1.

—_ and Coauthors, 2013: The Global/Regional Integrated Model system (GRIMs). Asia-Pac. J. Atmos. Sci., 49, 219-243, https:// doi.org/10.1007/s13143-013-0023-0.

Jin, C.-S., C.-H. Ho, J.-H. Kim, D.-K. Lee, D.-H. Cha, and S.-W. Yeh, 2013: Critical role of northern off-equatorial sea surface temperature forcing associated with central Pacific El Niño in more frequent tropical cyclone movements toward East Asia. J. Climate, 26, 2534-2545, https://doi.org/10.1175/JCLI-D-12-00287.1.

— D.-H. Cha, D.-K. Lee, M.-S. Suh, S.-Y. Hong, H.-S. Kang, and C.-H. Ho, 2015: Evaluation of climatological tropical cyclone activity over the western North Pacific in the CORDEXEast Asia multi-RCM simulations. Climate Dyn., 47, 765-778, https://doi.org/10.1007/s00382-015-2869-6.

Kain, J. S., 2004: The Kain-Fritsch convective parameterization: An update. J. Appl. Meteor., 43, 170-181, https://doi.org/ 10.1175/1520-0450(2004)043<0170:TKCPAU>2.0.CO;2.

Kim, D., C.-S. Jin, C.-H. Ho, J. Kim, and J.-H. Kim, 2015: Climatological features of WRF-simulated tropical cyclones over the western North Pacific. Climate Dyn., 44, 3223-3235, https://doi.org/10.1007/s00382-014-2410-3.

Kim, H.-S., C.-H. Ho, J.-H. Kim, and P.-S. Chu, 2012: Track-pattern-based model for seasonal prediction of tropical cyclone activity in the western North Pacific. J. Climate, 25, 4660-4678, https://doi.org/10.1175/JCLI-D-11-00236.1.

Kim, J. H., C. H. Ho, and P. S. Chu, 2010: Dipolar redistribution of summertime tropical cyclone genesis between the Philippine Sea and the northern South China Sea and its possible mechanisms. $J$. Geophys. Res., 115, D06104, https://doi.org/10.1029/2009jd012196.

Knutson, T. R., J. J. Sirutis, M. Zhao, R. E. Tuleya, M. Bender, G. A. Vecchi, G. Villarini, and D. Chavas, 2015: Global projections of intense tropical cyclone activity for the late twentyfirst century from dynamical downscaling of CMIP5/RCP4.5 scenarios. J. Climate, 28, 7203-7224, https://doi.org/10.1175/ JCLI-D-15-0129.1.

Landman, W. A., A. Seth, and S. J. Camargo, 2005: The effect of regional climate model domain choice on the simulation of tropical cyclone-like vortices in the southwestern Indian Ocean. J. Climate, 18, 1263-1274, https://doi.org/10.1175/JCLI3324.1.

Lee, D. K., D. H. Cha, and H. S. Kang, 2004: Regional climate simulation of the 1998 summer flood over East Asia. J. Meteor. Soc. Japan, 82, 1735-1753, https://doi.org/10.2151/jmsj.82.1735.

Lee, J.-W., and S.-Y. Hong, 2014: Potential for added value to downscaled climate extremes over Korea by increased resolution of a regional climate model. Theor. Appl. Climatol., 117, 667-677, https://doi.org/10.1007/s00704-013-1034-6.

Manganello, J. V., and Coauthors, 2014: Future changes in the western North Pacific tropical cyclone activity projected by a multidecadal simulation with a 16-km global atmospheric GCM. J. Climate, 27, 7622-7646, https://doi.org/10.1175/JCLID-13-00678.1.
Mei, W., and S.-P. Xie, 2016: Intensification of landfalling typhoons over the northwest Pacific since the late 1970s. Nat. Geosci., 9, 753-757, https://doi.org/10.1038/ngeo2792.

Murakami, H., B. Wang, and A. Kitoh, 2011a: Future change of western North Pacific typhoons: Projections by a $20-\mathrm{km}-\mathrm{mesh}$ global atmospheric model. J. Climate, 24, 1154-1169, https:// doi.org/10.1175/2010JCLI3723.1.

_ , R. Mizuta, and E. Shindo, 2011b: Future changes in tropical cyclone activity projected by multi-physics and multi-SST ensemble experiments using the 60-km-mesh MRI-AGCM. Climate Dyn., 39, 2569-2584, https://doi.org/10.1007/s00382011-1223-x.

_- and Coauthors, 2012: Future changes in tropical cyclone activity projected by the new high-resolution MRI-AGCM. J. Climate, 25, 3237-3260, https://doi.org/10.1175/JCLI-D-1100415.1.

Oh, S.-G., M.-S. Suh, and D.-H. Cha, 2013: Impact of lateral boundary conditions on precipitation and temperature extremes over South Korea in the CORDEX regional climate simulation using RegCM4. Asia-Pac. J. Atmos. Sci., 49, 497509, https://doi.org/10.1007/s13143-013-0044-8.

Park, J.-H., S.-G. Oh, and M.-S. Suh, 2013: Impacts of boundary conditions on the precipitation simulation of RegCM4 in the CORDEX East Asia domain. J. Geophys. Res., 118, 16521667, https://doi.org/10.1002/jgrd.50159.

Roberts, M. J., and Coauthors, 2015: Tropical cyclones in the UPSCALE ensemble of high-resolution global climate models. J. Climate, 28, 574-596, https://doi.org/10.1175/JCLID-14-00131.1.

Shen, W., J. Tang, Y. Wang, S. Wang, and X. Niu, 2016: Evaluation of WRF model simulations of tropical cyclones in the western North Pacific over the CORDEX East Asia domain. Climate Dyn., 48, 2419-2435, https://doi.org/10.1007/s00382-016-3213-5.

Skamarock, W. C., and Coauthors, 2008: A description of the Advanced Research WRF version 3. NCAR Tech. Note NCAR/ TN-475+STR, 113 pp., https://doi.org/10.5065/D68S4MVH.

Stowasser, M., Y. Wang, and K. Hamilton, 2007: Tropical cyclone changes in the western North Pacific in a global warming scenario. J. Climate, 20, 2378-2396, https://doi.org/10.1175/ JCLI4126.1.

Sugi, M., H. Murakami, and J. Yoshimura, 2012: On the mechanism of tropical cyclone frequency changes due to global warming. J. Meteor. Soc. Japan, 90, 397-408, https://doi.org/10.2151/ jmsj.2012-A24.

Suh, M.-S., S.-G. Oh, D.-K. Lee, D.-H. Cha, S.-J. Choi, C.-S. Jin, and S.-Y. Hong, 2012: Development of new ensemble methods based on the performance skills of regional climate models over South Korea. J. Climate, 25, 7067-7082, https://doi.org/ 10.1175/JCLI-D-11-00457.1.

Tu, J.-Y., C. Chou, and P.-S. Chu, 2009: The abrupt shift of typhoon activity in the vicinity of Taiwan and its association with western North Pacific-East Asian climate change. J. Climate, 22, 3617-3628, https://doi.org/10.1175/2009JCLI2411.1.

Vitart, F., J. Anderson, and W. Stern, 1997: Simulation of interannual variability of tropical storm frequency in an ensemble of GCM integrations. J. Climate, 10, 745-760, https://doi.org/ 10.1175/1520-0442(1997)010<0745:SOIVOT $>2.0 . C O ; 2$.

Wu, L., Z. Wen, R. Huang, and R. Wu, 2012: Possible linkage between the monsoon trough variability and the tropical cyclone activity over the western North Pacific. Mon. Wea. Rev., 140, 140-150, https://doi.org/10.1175/MWR-D-11-00078.1.

, and Coauthors, 2014: Simulations of the present and latetwenty-first-century western North Pacific Tropical cyclone 
activity using a regional model. J. Climate, 27, 3405-3424, https://doi.org/10.1175/JCLI-D-12-00830.1.

Yamada, Y., K. Oouchi, M. Satoh, H. Tomita, and W. Yanase, 2010: Projection of changes in tropical cyclone activity and cloud height due to greenhouse warming: Global cloudsystem-resolving approach. Geophys. Res. Lett., 37, L07709, https://doi.org/10.1029/2010GL042518.

Zhang, Q., L. Wu, and Q. Liu, 2009: Tropical cyclone damages in China 1983-2006. Bull. Amer. Meteor. Soc., 90, 489-496, https://doi.org/10.1175/2008BAMS2631.1.
Zhang, W., and Coauthors, 2016: Influences of natural variability and anthropogenic forcing on the extreme 2015 accumulated cyclone energy in the western north Pacific [in "Explaining Extreme Events of 2015 from a Climate Perspective"]. Bull. Amer. Meteor. Soc., 97 (12), S131-S135, https://doi.org/ 10.1175/BAMS-D-16-0146.1.

Zou, L., Y. Qian, T. Zhou, and B. Yang, 2014: Parameter tuning and calibration of RegCM3 with MIT-Emanuel cumulus parameterization scheme over CORDEX East Asia domain. J. Climate, 27, 7687-7701, https://doi.org/10.1175/JCLI-D-14-00229.1. 